\title{
Optimum charging scheme of Electric Vehicle (EV) battery
}

\author{
Abdul Fattah, Abdul Goffar Khan
}

\begin{abstract}
Tubular plate lead acid deep cycle batteries are becoming more and more popular in Bangladesh to run electrical vehicles. A China made low cost charger is commonly used to charge these batteries which takes approximately 10 hours to full charge. In this paper, comparative results of charging EV tubular battery using conventional charger as well as Universal Battery Tester (UBT) have been reported. Total 8 different types of charging methods have been tested and different parameters like temperature rise, change of specific gravity of the electrolyte in the battery, variation of voltage and current, stored AmpereHour etc. have been observed. Thereby a comparatively quick charging method has been proposed which can ensure less temperature rise and therefore better efficiency and longer battery life.
\end{abstract}

Keywords - Electrical Vehicle, Charging, Tubular Battery, Specific Gravity, Ampere-Hour, Tubular Plate.

\section{INTRODUCTION}

Electrical vehicles are becoming more and more popular day by day and it is expected that a big percentage of the petroleum based cars will be replaced from the road by electrical vehicles by the year of 2030 [1]. Petroleum cars are responsible for carbon-di-oxide emission, temperature rise of the environment as well as sound pollution. Electrical vehicles are free from such objections. However, the major drawback of electrical vehicles is long recharging (refueling) time. While petroleum cars can be refueled within a few minutes, electrical vehicles require 8 to 10 hours for recharging [2]. This issue made electrical vehicles unfit and less popular for long distance travel.

Usually most electrical vehicles in Bangladesh use lead-acid deep cycle batteries of different capacity ratings from different manufacturers [3]. High temperature rise is observed when these batteries are forced charged to reduce the charging time. Temperature rise is harmful for batteries; it affects the amperehour capacity, responsible for low efficiency and ultimately reduces battery life $[4,5,6]$.

Different attempts have been made to reduce the charging time of batteries which are being used to run electrical vehicles to

\author{
Abdul Fattah \\ American International University - Bangladesh \\ Dhaka, Bangladesh \\ abdul.bd.fattah.eee@gmail.com
}

\section{Abdul Goffar Khan}

American International University - Bangladesh

Dhaka, Bangladesh

agmagk@gmail.com make them suitable for long distance travel [7].

New battery technologies have been proposed which can be charged within very short time (as low as 10 to 15 minutes) and can supply energy for longer period (several hours), thus are suitable for long distance travel [8]. However such battery technologies are comparatively costly (because of new technology and less commercial production) and need special charging stations as well $[8,9]$.

In Bangladesh mostly tubular plate Lead-acid batteries are used for EV operation. One such popular model is EV140AH $[3,10]$. The voltage ratings of these batteries are $12 \mathrm{~V}$. An inverter converts DC 48 - 60V energy (depending on EV size) into $220 \mathrm{~V}$ AC. A motor is used to run most of the electrical vehicles using this AC energy [11]. Therefore total 4 - 5 numbers of such batteries are connected in series and charged by a $48-60 \mathrm{~V}$ charger (Charging voltage should be a bit higher to allow current to flow while charging) [11]. In this research two different chargers, one is Chinese made 30A charger (called as 'Local Charger' afterwards in this paper) and another is a standard Universal Battery charger (called as 'UBT' afterwards in this paper) have been used to charge EV140AH batteries. Different charging methods have been tested on same samples of batteries. After each charge/test, the batteries were discharged through $\mathrm{C} 20$ rate [6] to make them ready for next charge/test.

\section{SPECIFICATION OF BATTERY AND CHARGER}

The specifications of the battery used for testing in this research are given in Table 1 below. It is a deep cycle low maintenance lead-acid battery designed to be regularly deeply discharged to utilize most of its capacity. Low maintenance batteries can be refilled with distilled water [12] only (water without any minerals) when acid level goes down below the level marked as "LOWER LEVEL" on the container.

\section{TABLE 1. SPECIFICATIONS OF EV140AH BATTERY UNDER TEST}

\begin{tabular}{|c|c|c|}
\hline Parameter & Type & Remarks \\
\hline $\begin{array}{l}\text { Brand and } \\
\text { country }\end{array}$ & S FORCE & $\begin{array}{c}\text { Saif Powertec Battery Limited, } \\
\text { Bangladesh. }\end{array}$ \\
\hline Battery Type & $\begin{array}{l}\text { Deep Cycle } \\
\text { Battery }\end{array}$ & Low Maintenance lead-acid Battery \\
\hline Positive Plate & $\begin{array}{c}\text { Tubular } \\
\text { Sulphated Plate }\end{array}$ & $\begin{array}{c}20 \text { numbers of tube on each positive } \\
\text { plate, } \\
4 \text { numbers of plate per cell }\end{array}$ \\
\hline Negative Plate & $\begin{array}{l}\text { Green pasted } \\
\text { plate }\end{array}$ & $\begin{array}{c}\text { Rectilinear Flat Grid plate, } 5 \\
\text { numbers of plate per cell }\end{array}$ \\
\hline $\begin{array}{l}\text { Numbers of cell } \\
\text { in one battery }\end{array}$ & & 6 cells \\
\hline Grid Alloy & Lead & Mixed with $2.5 \%$ antimonial grid \\
\hline
\end{tabular}




\begin{tabular}{|c|c|c|}
\hline $\begin{array}{c}\text { Separator Types } \\
{[13]}\end{array}$ & PE Sleeve Type & $60 \%$ porosity \\
\hline $\begin{array}{c}\text { Container } \\
{[14]}\end{array}$ & $\mathrm{EV}$ & Weight is $1.645 \mathrm{~kg}$ \\
\hline $\begin{array}{c}\text { Specific gravity } \\
\text { of acid }\end{array}$ & $\begin{array}{c}1.280-1.295 \\
\text { when fully } \\
\text { charged }\end{array}$ & Sulfuric acid \\
\hline $\begin{array}{c}\text { Volume of acid } \\
\text { per cell }\end{array}$ & $1290 \mathrm{ml}$ & \\
\hline $\begin{array}{c}\text { Terminal } \\
\text { Voltage }\end{array}$ & $12 \mathrm{~V}$ & $37.28 \mathrm{~kg}$ (with acid) \\
\hline $\begin{array}{c}\text { Ampere-Hour } \\
\text { rating }\end{array}$ & $140 \mathrm{AH}$ & \\
\hline Weight & $24.89 \mathrm{~kg}$ & \\
\hline
\end{tabular}

A photograph of the Battery is given below in Fig. 1.

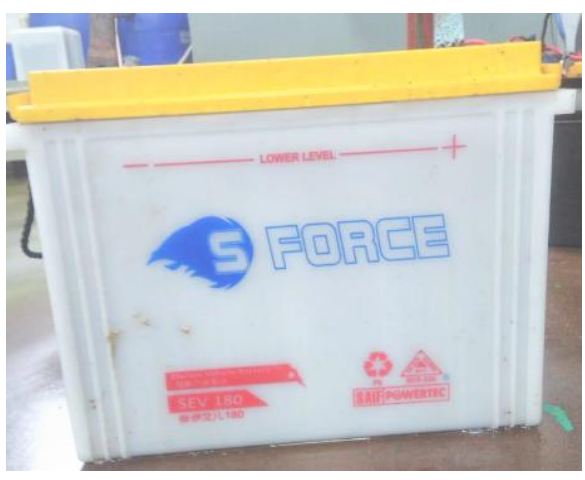

Fig. 1. Photograph of the Battery

The specification of the Local charger used for charging the battery is given in Table 2 below.

TABLE 2. SPECIFICATIONS OF 'LOCAL CHARGER'

\begin{tabular}{|l|l|}
\hline Brand and country & $\begin{array}{l}\text { Ningbo Dowedo International } \\
\text { Co., Ltd., China }\end{array}$ \\
\hline Input & $220 \mathrm{~V}, 50 \mathrm{~Hz}, \mathrm{ac}$ \\
\hline Output Charging Voltage & 60 Volts, DC \\
\hline Charging mode & Constant voltage \\
\hline Maximum Charging Current & 30 Amperes \\
\hline Voltage rating of each battery & 12 Volts \\
\hline $\begin{array}{l}\text { Number of batteries can be } \\
\text { connected in series at a time }\end{array}$ & 5 Nos. \\
\hline Maximum Charging Current & 30 Amperes \\
\hline Min Charging Current & 0 Amps \\
\hline
\end{tabular}

A photograph of the Local charger is given below in Fig. 2.

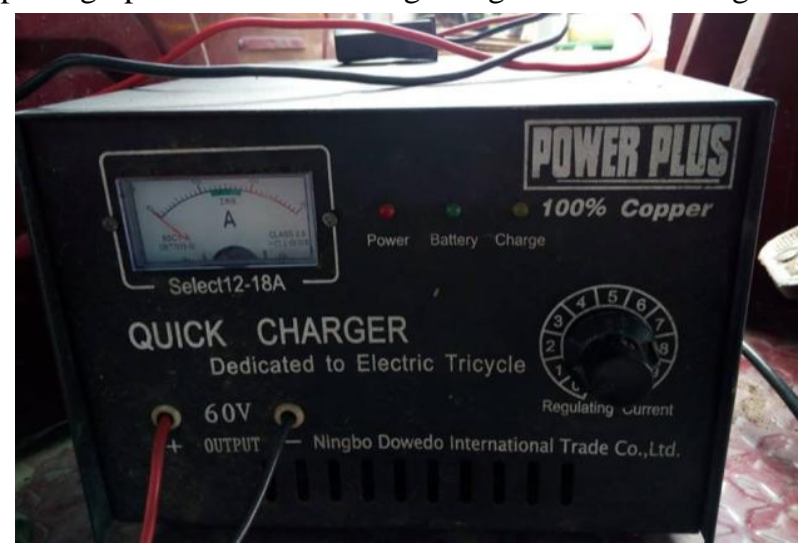

Fig. 2. : Photograph of the Local charger

The specification of the UBT charger used for charging the battery is given in Table 3 below.

TABLE 3. : SPECIFICATIONS OF UNIVERSAL BATTERY TESTER

\begin{tabular}{|l|l|}
\hline Brand and country & Digatron, Germany. \\
\hline Software & BTS600 \\
\hline Input & $400 \mathrm{~V}, 3$ phase, $50 / 60 \mathrm{~Hz}$ \\
\hline $\begin{array}{l}\text { Maximum Output } \\
\text { (Charging) Voltage }\end{array}$ & 18 Volts \\
\hline Charging mode & $\begin{array}{l}\text { Constant voltage, constant current, } \\
\text { constant power. }\end{array}$ \\
\hline $\begin{array}{l}\text { Voltage rating of each } \\
\text { battery }\end{array}$ & 12 Volts \\
\hline $\begin{array}{l}\text { Number of charging circuits } \\
\text { at same time }\end{array}$ & 10 no. \\
\hline Maximum Charging Current & $100 \mathrm{Amperes}$ \\
\hline Min Charging Current & $0.5 \mathrm{Amps}$ \\
\hline
\end{tabular}

A photograph of universal battery tester is given below in Fig. 3

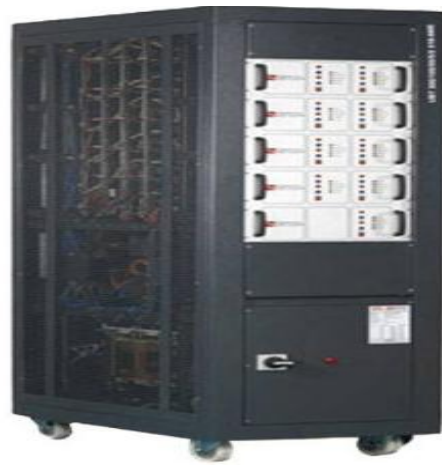

Fig. 3. : Photograph of the Universal Battery tester

\section{CHARGING AND DISCHARGING METHODS}

The battery is tested through different charging methods as listed in Table 4 below.

TABLE 4. : LIST OF TESTS CONDUCTED ON THE BATTERY

\begin{tabular}{|c|l|}
\hline Test No. & \multicolumn{1}{c|}{ Type } \\
\hline 1 & $\begin{array}{l}\text { Charging battery with local charger, both the } \\
\text { voltage and currents are variable } \\
\text { Constant current charging at 14A. }\end{array}$ \\
\hline 2 & $\begin{array}{l}\text { Constant voltage charging at 14.8V, maximum } \\
\text { current is limited to 100A. }\end{array}$ \\
\hline 3 & Constant current charging at 21A. \\
\hline 5 & $\begin{array}{l}\text { Constant voltage charging at 14.8V, maximum } \\
\text { current is limited to 28A. }\end{array}$ \\
\hline 6 & Charging with 90A pulse current. \\
\hline 7 & Charging with 28A pulse current. \\
\hline 8 & Charging with 40A pulse current. \\
\hline
\end{tabular}

Test no. 1 is done using the local charger, having the output charging voltage of $60 \mathrm{~V}$. Therefore 5 numbers of identical batteries of same ratings have been connected in series across the charger. All other tests (test no.2 to test no. 8) were done using the UBT having maximum output charging voltage of 
$18 \mathrm{~V}$, which can be adjusted to different desired voltages through the built-in software. Therefore a single battery, chosen randomly from the row of the batteries used in test 1 , is connected across the charger.

Indication of full charge: The indication of full charge of the battery can be ascertained through following measurements,

(i) Measurement of specific gravity of the acid in the battery,

(ii) Measurement of the terminal voltage and (iii) Measurement of charging current. Battery is full charged if the specific gravity rises to 1.270 [15]. Terminal voltage and current parameters were measured in parallel by BTS600 software (Table 3) and Specific Gravity measured manually in every hour. During constant current charging, the terminal voltage of the battery rises slowly, reaches to a maximum, then remains constant or shows a declination. If the voltage reading remains same for three consecutive measurements or a small declination is observed, the battery is fully charged. On the other hand, in constant voltage charging method, initially the charging current is too high, and then it slowly decreases and finally becomes almost constant when the battery is fully charged [5]. The battery is disconnected from the charger if any of the above indications are observed. The temperature rise of the battery is also monitored and the battery is disconnected for protection if excessive heating is observed. A rise of $50^{\circ} \mathrm{C}$ is the allowable limit $[4,5,6]$.

Pulse current charging: There are different methods of charging a battery. Constant voltage and constant current charging are very popular and commonly used. In this research pulse current charging has been tested along with constant voltage and constant current charge. A current of a constant magnitude is allowed to flow through the battery for a short period, say for 60 seconds. Then the battery is left at rest for few second. After that the battery is connected to a load to discharge for a short period, thus a negative current pulse is applied. Thereby a Charge-Pause-Discharge cycle is formed which is repeated till the battery is fully charged. The technique is explained in the following Fig. 4. The magnitude and time period of the charging pulse is selected to different values as obtained from standards $[6,16]$, whereas the magnitude of discharging current is taken $10 \%$ to that of charging pulse. The different pulse current charging cycle, as applied in this research, are given in Tables 5, 6 and 7 below.

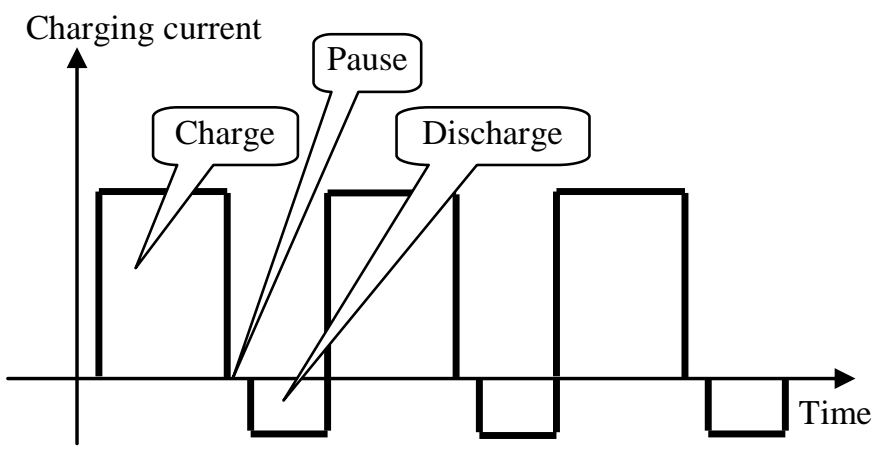

Fig. 4. : Sequence of pulse current charging.
TABLE 5. : : 90A PULSE CURRENT CHARGING CYCLE

\begin{tabular}{|c|c|c|c|}
\hline Program & Current & Time & Ampere-hour \\
\hline Charge & $90 \mathrm{~A}$ & 60 seconds & 1.503 \\
\hline Pause & 0 Amperes & 5 seconds & 0 \\
\hline Discharge & $9 \mathrm{~A}$ & 10 seconds & -0.025 \\
\hline \multicolumn{2}{|c|}{ Total Ampere-hour absorbed } & 1.498 \\
\hline
\end{tabular}

TABLE 6. : 28A PULSE CURRENT CHARGING CYCLE

\begin{tabular}{|c|c|c|c|}
\hline Program & Current & Time & Ampere-hour \\
\hline Charge & 28A & 60 seconds & 0.467 \\
\hline Pause & 0 Amperes & 5 seconds & 0 \\
\hline Discharge & $2.8 \mathrm{~A}$ & 10 seconds & $-7.78 \times 10^{-03}$ \\
\hline \multicolumn{2}{|r|}{ Total Ampere-hour absorbed } & 0.459 \\
\hline
\end{tabular}

TABLE 7. 40A PULSE CURRENT CHARGING CYCLE

\begin{tabular}{|c|c|c|c|}
\hline Program & Current & Time & Ampere-hour \\
\hline Charge & $40 \mathrm{~A}$ & 60 seconds & 0.668 \\
\hline Pause & 0 Amperes & 5 seconds & 0 \\
\hline Discharge & $4 \mathrm{~A}$ & 10 seconds & -0.0033 \\
\hline \multicolumn{2}{|c|}{ Total Ampere-hour absorbed } & 0.6647 \\
\hline
\end{tabular}

Discharging: After each charging test, the battery is discharged at a discharging rate of @ C20 [6], a period of 20 hours. UBT discharges the battery by 7A current for continuously 20hours. Then the next test is started. To avoid deep discharge [5], the terminal voltage of the battery is monitored. The battery is disconnected from the load if the terminal voltage goes below $10.5 \mathrm{~V}$ while discharging.

\section{TEST RESULTS}

The results of different tests have been described in the following sections. The parameters measured during the tests are (i) terminal voltage, (ii) charging current (iii) variation of specific gravity and (iv) temperature rise.

Test no. 1 was conducted by local charger. From test no. 2 to test no. 8, we have used UBT to complete the tests.

\section{A. Test result of test no. 1}

During this test the variation of terminal voltage and charging current with time is shown in Fig.5. It is observed that the terminal voltage does not remain constant during test, rather it increases slowly. The initial current starts from 17A and falls gradually to $7 \mathrm{~A}$. The voltage rise in all the 5 batteries (which are connected in series) is almost similar. Although the local charger marked as $30 \mathrm{~A}$, it is found during the test it can supply maximum 17A. It is evident from the graph that it took almost 10 hours to full charge of the batteries.

\section{B. Test result of test no. 2}

It is a constant current test. The observed results are shown in Fig. 6 below. The Charging current is kept constant at 14A. The terminal voltage is found to increase gradually till full charge. In this test also it is evident from the graph that it took almost 10 - 13 hours to full charge of the battery. 


\section{Test result of test no. 3}

It is a constant voltage charging procedure. While keeping voltage constant at $14.8 \mathrm{~V}$, the variation of current is observed. A current of $100 \mathrm{~A}$ was the maximum charging limit. The obtained result is shown in Fig. 7 below. At beginning the charging current has been 100A. However the current dropped sharply and began to saturate till full charge is obtained. A charging time of $6-8$ hours is required in this case.

\section{Test result of test no. 4}

It is a constant current test. In this test a constant current of $21 \mathrm{~A}$ is being supplied while the terminal voltage is allowed to rise. The result is shown in Fig. 8 below. The charging time is found to be $7-8$ hours. It is interesting to observe that the terminal voltage rises gradually as charging is going on and reaches to a maximum, and then it comes down, indicating full charge. The battery is disconnected immediately from the charger, because high temperature rise is observed at this condition (Table 8).

\section{E. Test result of test no. 5}

Again it is a constant voltage charging at $14.8 \mathrm{~V}$ but the maximum current limit is reduced to $28 \mathrm{~A}$ (In a previous test it was 100A). The variation of charging current is shown in Fig. 9 below. It is observed that, the battery was charged by $28 \mathrm{~A}$ current for 4 hours at the beginning. Then the current fell gradually to a saturation value indicating full charge. $80 \%$ of charge was completed in 8 hours. Total charging time required is 10 hours.

\section{F. Test result of test no. 6}

This is the said pulse current charging test as explained in Fig.4 above. The sequence of Charge-Pause-Discharge has shown in Table 5. The magnitude of charging pulse current is 90A. The variation of terminal voltage is shown in Fig. 10. It is observed that the voltage rises during charging and falls to a lower value while discharging. However the overall voltage rise gradually reaches to a maximum and then starts to fall down, indicating full charge. The battery is charged fully within a comparatively short time of 3 hours, but the temperature rise is excessive, about $91^{0} \mathrm{C}$.

\section{G. Test result of test no. 7}

Again it is the pulse current charging test, but the magnitude of the charging pulse current is set at a reduced value of $28 \mathrm{~A}$. In the previous test the charging current was too high which caused increase in battery temperature. Therefore it was decided to charge the battery at a lower current. The sequence of Charge-Pause-Discharge is shown in Table 6. The variation of terminal voltage is shown in Fig. 11. It is observed that the voltage rises in a similar way, as in the previous test and falls to a lower value while discharging. However the overall voltage rises gradually and reaches to a maximum and then starts fall down, indicating full charge. However a charging time 7.5 of hours is observed in this case, which is a bit longer compared to the previous test. The temperature rise is $54^{0} \mathrm{C}$ only, which is not too high, as expected.

\section{H. Test result of test no. 8}

It is a pulse charging process. In the previous test the charging current was too low which causes the temperature rise within safe value. But comparatively longer charging time was required. Therefore it was decided to repeat the same test with an increased value of charging current, set at 40A. Similar variation of voltage is observed here as shown in Fig.12 below. As expected, the charging time required is reduced to 4 hours with a temperature rise of $55^{\circ} \mathrm{C}$, which is within acceptable limit.

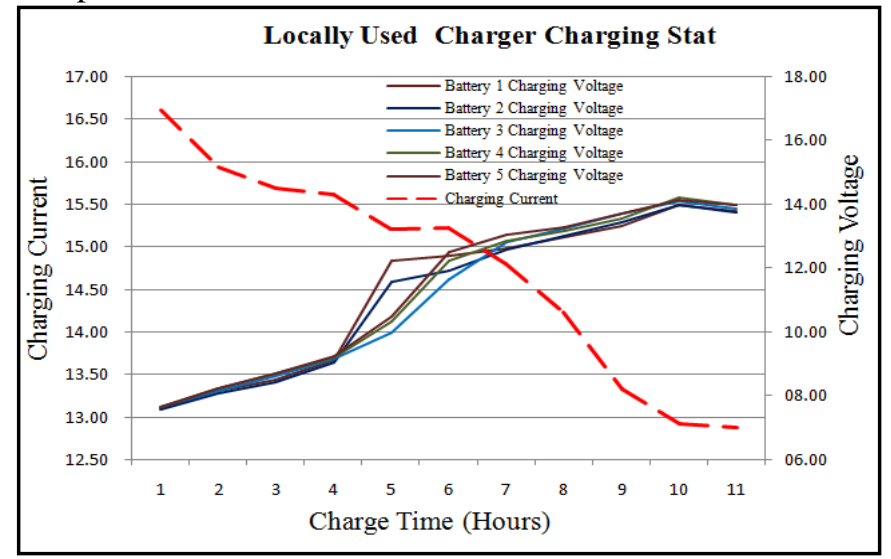

Fig. 5. Variation of voltage and current with time in test no.1

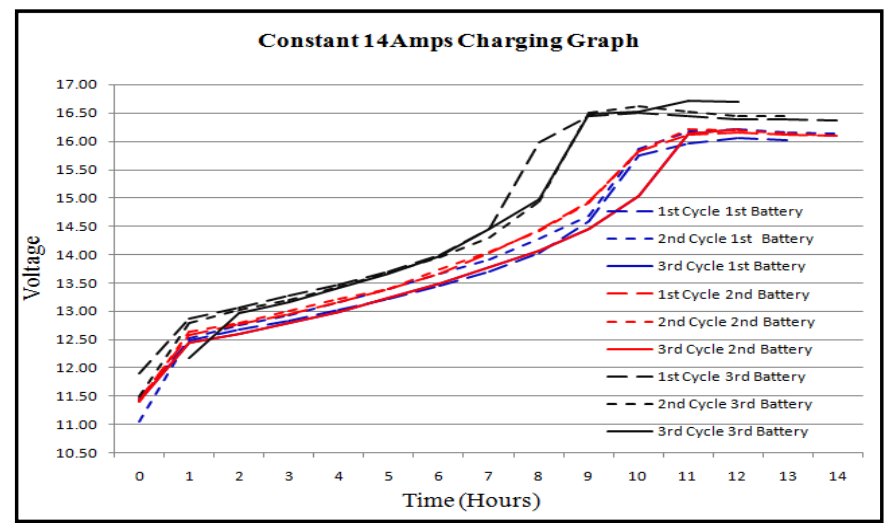

Fig. 6. Variation of voltage with time in test no. 2

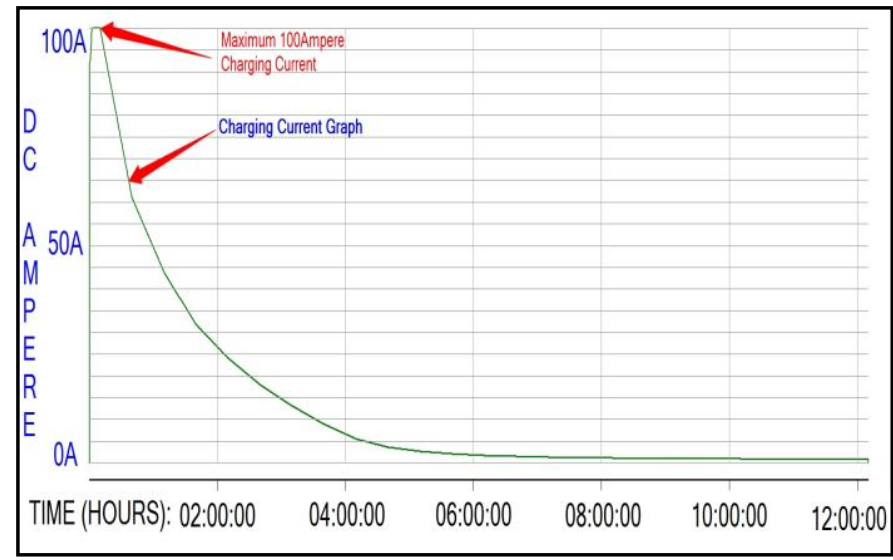


Fig. 7. Variation of current with time in test no.3.

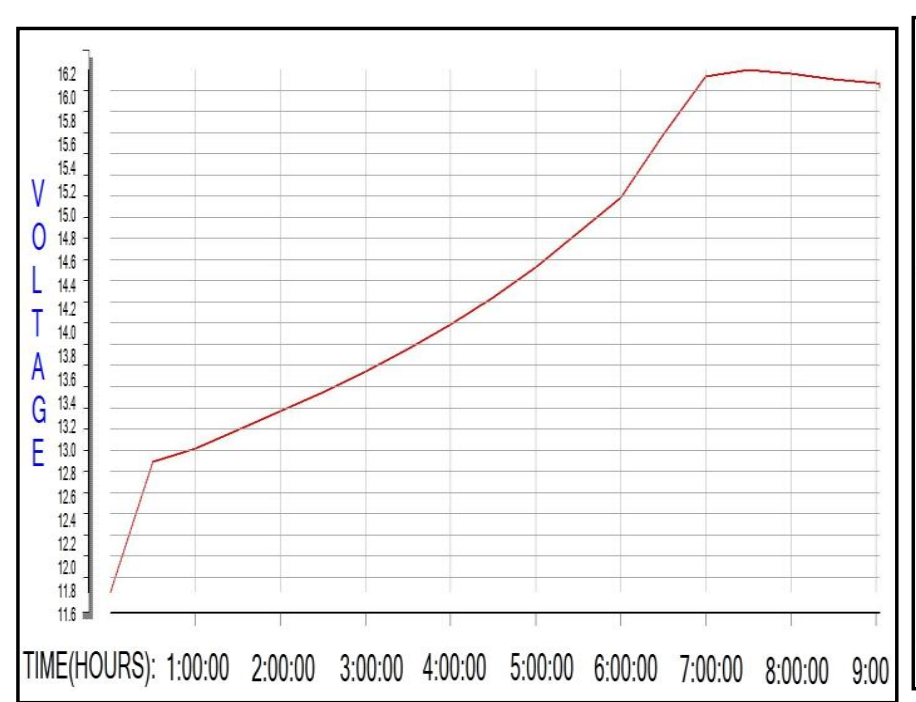

Fig. 8. Variation of voltage with time in test no.4

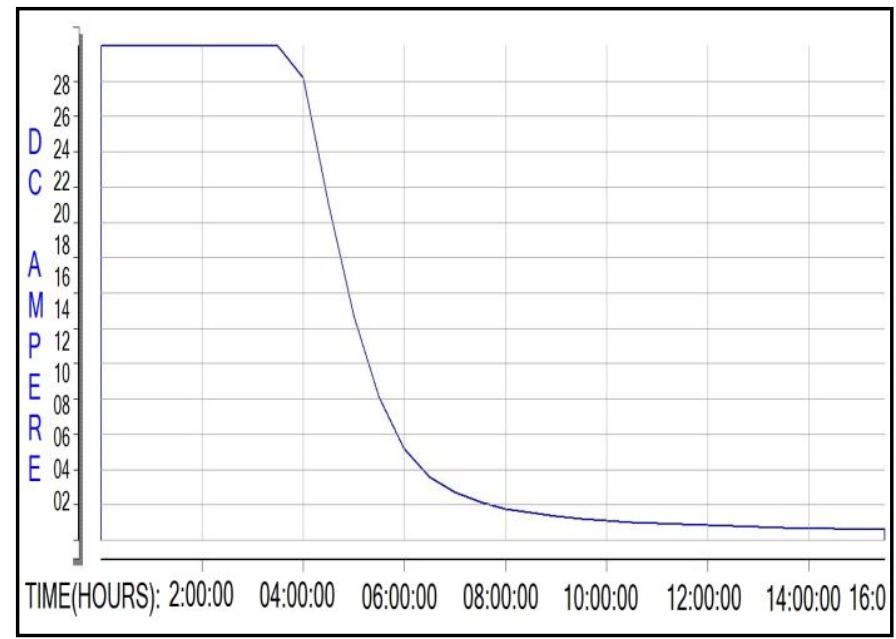

Fig. 9. Variation of current with time in test no.5

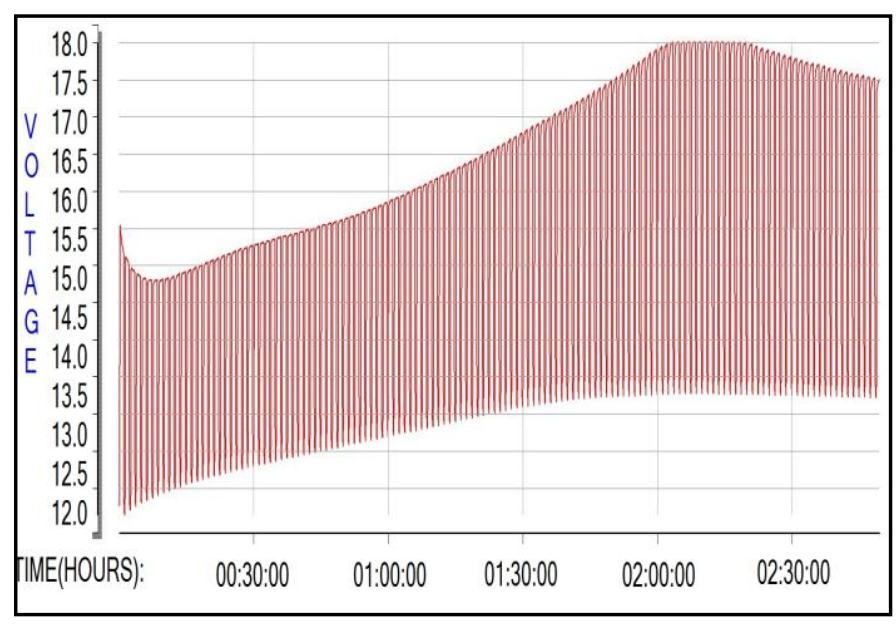

Fig. 10. Variation of voltage with time in test no.6.

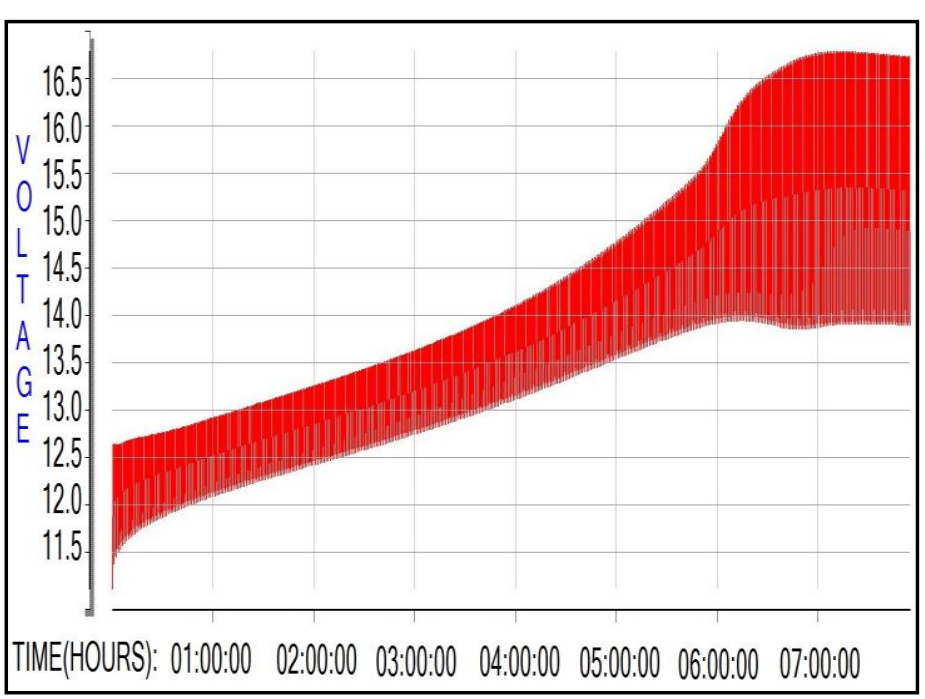

Fig. 11. Variation of voltage with time in test no.7

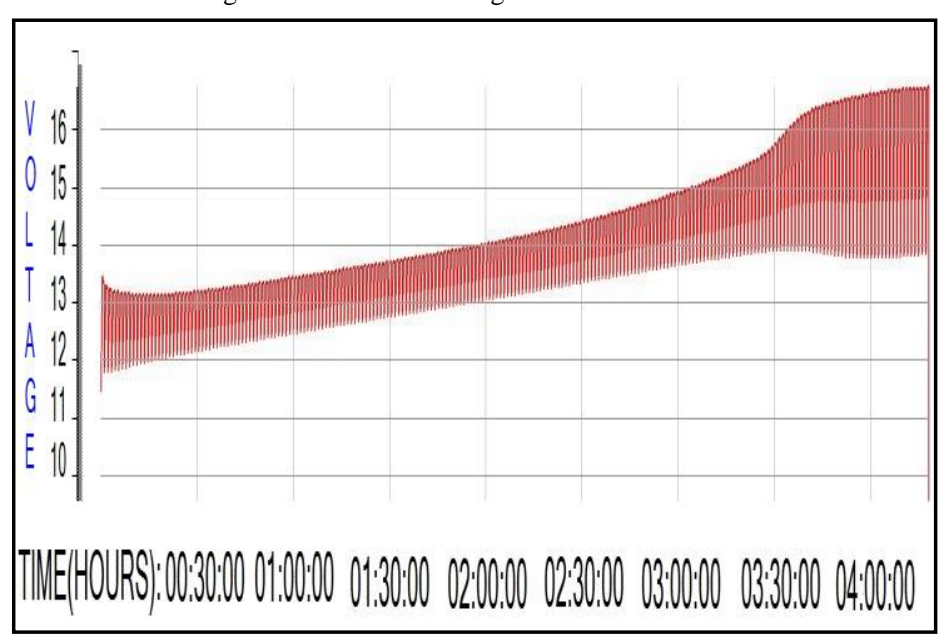

Fig. 12. Variation of voltage with time in test no.8.

\section{DISCUSSION}

The findings from all the above mentioned tests are summarized in the Table 8 below. It is observed from the table that the maximum charging time is 13 hours with a temperature rise of $44^{\circ} \mathrm{C}$. On the other hand the quickest charging is possible within 3 hours but the temperature rise is $91^{\circ} \mathrm{C}$, which is too high and harmful for the battery life. As a compromise between these two extreme values, an optimum charging scheme could be found which correspond to test no.8. Therefore Constant voltage charging at $14.8 \mathrm{~V}$ with a maximum current limit to $100 \mathrm{~A}$ charging scheme is recommended for moderate charging and Pulse 40A charging scheme is recommended for fast charging for 140AH@C20 battery. 
TABLE 8: Summary of all tests

\begin{tabular}{|c|c|c|c|c|c|c|c|c|}
\hline Test No. & 1 & 2 & 3 & 4 & 5 & 6 & 7 & 8 \\
\hline $\begin{array}{l}\text { Charging } \\
\text { Current in } \\
\text { Amperes }\end{array}$ & Variable & 14 & Variable & 21 & Variable & Pulse & Pulse & Pulse \\
\hline $\begin{array}{c}\text { Charging } \\
\text { Voltage in } \\
\text { Volt }\end{array}$ & Variable & Variable & 14.8 & Variable & 14.8 & Variable & Variable & Variable \\
\hline $\begin{array}{c}\text { Charging } \\
\mathrm{AH} \text { and Sp. } \\
\text { Gr. }\end{array}$ & $\begin{array}{c}\text { (Haven't } \\
\text { Calculated) } \\
\text { and } 1.285 \\
-1.295\end{array}$ & $\begin{array}{c}170-180 \\
\text { and } \\
1.275- \\
1.285\end{array}$ & $\begin{array}{c}150-155 \\
\text { and } \\
1.275- \\
1.285\end{array}$ & $\begin{array}{c}155-160 \\
\text { and } \\
1.270- \\
1.280\end{array}$ & $\begin{array}{c}130-150 \\
\text { and } \\
1.275- \\
1.270\end{array}$ & $\begin{array}{c}200 \\
\text { and } \\
1.270\end{array}$ & $\begin{array}{c}155-175 \\
\text { and } \\
1.250\end{array}$ & $\begin{array}{c}140- \\
150 \\
\text { and } 1.225\end{array}$ \\
\hline $\begin{array}{c}\text { Max Amps } \\
\text { and Volt. }\end{array}$ & $\begin{array}{c}16.92 \mathrm{~A} \\
\text { and } \\
15.49 \mathrm{~V}\end{array}$ & $16.71 \mathrm{~V}$ & $100 \mathrm{~A}$ & $16.62 \mathrm{~V}$ & $28 \mathrm{~A}$ & $\begin{array}{c}90 \mathrm{~A} \text { and } \\
18 \mathrm{~V}\end{array}$ & $\begin{array}{c}28 \mathrm{~A} \text { and } \\
16.5 \mathrm{~V}\end{array}$ & $\begin{array}{c}40 \mathrm{~A} \text { and } \\
16.5 \mathrm{~V}\end{array}$ \\
\hline $\begin{array}{c}\text { Discharge } \\
\text { Time(Hours) } \\
\text { / Mileage } \\
(\mathrm{Km})\end{array}$ & $\begin{array}{c}120 \mathrm{Km} \\
\text { with } \\
220 \mathrm{Kg} \\
\text { load }\end{array}$ & $20 \mathrm{Hrs}$. & 19.5Hrs. & $\begin{array}{l}\text { Around } \\
20 \mathrm{Hrs} .\end{array}$ & $\begin{array}{l}19.5 \\
\text { Hrs. }\end{array}$ & 20 Hrs. & $\begin{array}{l}\text { Around } \\
20 \mathrm{Hrs} \text {. }\end{array}$ & $\begin{array}{c}19.25 \\
\text { Hrs. }\end{array}$ \\
\hline $\begin{array}{c}\text { Charging } \\
\text { Time } \\
\text { (Hours) }\end{array}$ & 10 & $12-13$ & $6-8$ & $8-9$ & $9-11$ & $2.5-3$ & $7-8$ & 4 \\
\hline $\begin{array}{c}\text { Max Temp } \\
{ }^{0} \mathrm{C}\end{array}$ & 53 & 44 & 50 & 55 & 37 & 91 & 54 & 55 \\
\hline
\end{tabular}

\section{CONCLUSION}

Different charging methods have been tested on EV140AH battery to find the most suitable charging scheme. It has been clearly observed from the test results that both the constant voltage and constant current charging require very long charging time of around 10 hours, indicating that overnight charging is needed. Whereas pulse current charging methods require comparatively shorter charging time, ranging from 3 to 6 hours and if the peak value of pulse current reduces, it keeps the charging temperature within range. However very high pulse current charging causes excessive temperature rise of as high as $91^{\circ} \mathrm{C}$, which is undesirable. A moderate pulse current of $40 \mathrm{~A}$ is found to be suitable for the said battery; the temperature rise is $55^{\circ} \mathrm{C}$, which is within permissible limit. Only three pulse current, $90 \mathrm{~A}, 40 \mathrm{~A}$ and $28 \mathrm{~A}$, have been tested in this research. Further research can be done by testing with other values of pulse currents. Thereby in the future work, one can find the best suitable pulse charging profile to charge the battery in the shortest possible time without increasing the temperature and affecting the other parameters.

\section{ACKNOWLEDGEMENT}

This work is supported by SAIF POWERTEC BATTERY LTD.

\section{REFERENCES}

[1] Daewoo securities, "KDB Daewoo Securities Research. I.China trip takeaways: The battle has already begun Rechargeable Batteries", October 26, 2015.
[2] Drew Kodjak, "Consumer Acceptance of Electric Vehicles in the US - Mobile Source Technical Review Subcommittee", icct, December 2012.

[3] Nasimul Kabir, 2017, "Prospect of Battery Industry In Bangladesh", [https://tinyurl.com/ydfbn7nf]. Accessed August 11, 2017.

[4] Electropedia, 2005, "Battery and Energy Technologies", [http://www.mpoweruk.com/life.htm]. Accessed 2005.

[5] Detchko Pavlov, "Lead-Acid Batteries - Science and Technology", Elsevier, 2011.

[6] Japanese Standards Association, "JAPANESE INDUSTRIAL STANDARD: Lead- acid starter batteries", Japan, 2006.

[7] Kevin Morrow, Donald Karner, James Francfort, "Plug-in Hybrid Electric Vehicle Charging Infrastructure Review", Idaho, USA, November 2008.

[8] Doug Kettles,"Electric Vehicle Charging Technology Analysis and Standards", Florida Solar Energy Center. February 2015.

[9] Shicheng, Mertens, Tempel, Kungl,Eichel,"Monolithic All-Phosphate Solid-State Lithium-Ion Battery with Improved Interfacial Compatibility" ACS Publications, USA, 2018.

[10] Ferdaus Ara Begum, 2018, "Battery run three wheelers need policy support”, [https://tinyurl.com/ybzn8c7s]. Accessed July 3, 2018.

[11] Lisa, May 26, 2016 "How the E Rickshaw works", [https://tinyurl.com/y7jvygop], QIANG SHENG, Accessed October $30,2018$.

[12] "What is Demineralised Water? Deionised or Distilled Water?", Vintage Road Haulage, 2018. [Online]. Available: http://www.vintageroadhaulage.com.au/faq/what-is-demineralisedwater/. [Accessed: 25- Sep- 2018]

[13] "Daramic ${ }^{\circledR} \quad \mathrm{HD}^{\mathrm{TM}}$ ", Daramic, 2018. [Online]. Available: https://www.daramic.com/products/daramic-hd-deep-cycle-specialty. [Accessed: 25- Sep- 2018]

[14] Manika Moulds Brochure, 1st ed. Mumbai: MANIKA MOULDS PVT.

[15] GB Industrial Battery, "Specific Gravity", [https://tinyurl.com/y8ttojbj], Accessed April 8, 2007.

[16] International Electrotechnical Comission "Secondary cells and batteries for photovoltaic energy system (PVES) - General requirements and methods of test", IEC 61427:2005E, Second edition, Switzerland, 2005.

[17] Adam Szczepanek.,Charles Botsford, "Fast Charging vs. Slow Charging: Pros and cons for the. New Age of Electric Vehicles." AeroVironment Inc., Monrovia, California, 2009.

[18] C. Simpson, "LM2576,LM3420,LP2951,LP2952. Battery Charging", Texas Instruments, 2011.

[19] Ministry of National InfrastructuresIsrael "Charging of Electric Vehicles Policy Principles, Ministry of National Infrastructures", Israel, 2011.

[20] JoachimSkov Johansen, "Fast-Charging Electric Vehicles using AC", Technical University of Denmark, 2013.

[21] EMSD, "Technical Guidelines on Charging Facilities for Electric Vehicles", pp 1-16, April, 2015.

[22] Jeremy Neubauer et.al., "Impact of Fast Charging on Life of EV. Batteries", National Renewable Energy Laboratory, Golden, Colorado, May 2015.

[23] Linear Technologies "Battery Charging and Management Solutions High Performance Analog IC's”, Linear Technologies, 2016.

[24] Brittney Miller, "Charging Lead Acid Batteries with care", [https://tinyurl.com/y9ev22tk]. Accessed September 25,2015.

[25] Timm, "Timms BMW repairs and information", [https://tinyurl.com/yczfklqr]. Accessed August, 2018. 


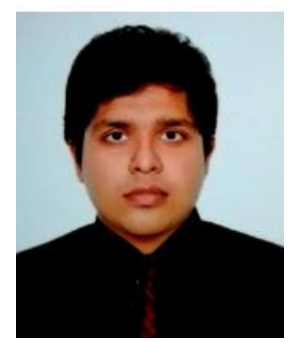

Abdul Fattah received B.Sc. degree in Electrical \& Electronics Engineering from United International University (UIU), Dhaka, Bangladesh in 2016 and now continuing M.Sc. in Electrical and Electronics Engineering in American International University - Bangladesh (AIUB). He started his career as Assistant Research Engineer in R\&D department in Solar Intercontinental (Solaric) Ltd. In 2015 and now working as Senior Officer in Quality Assurance Department of Saif Powertec Battery Limited. He has been involved with renewable solar energy power generation, distribution and optimization works and has been engaged with lead acid battery production, charging, testing and implementations. His research interests are mainly on renewable energy efficiency, control management and battery energy capacity, longevity and time management studies.

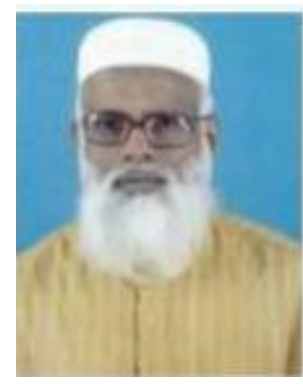

Dr. Muhammad Abdul Goffar Khan received his B.Sc. degree in Electrical and Electronics Engineering from the then Engineering College, Rajshahi in 1983 and M.Sc. in Electrical and Electronics Engineering from Bangladesh University of Engineering and Technology (BUET) in 1987. He received his $\mathrm{Ph} . \mathrm{D}$. degree from Indian Institute of Technology, Kanpur (IITK), India in 1997. He started his carrier as a lecturer in the Engineering College, Rajshahi, became Professor there in 2002. Presently he is working as a research professor in EEE department at American University of Bangladesh (AIUB). His research field includes Power electronics, Renewable Energy, Advanced Optical Fibers etc. He has published more than 80 papers in different journals and conference proceedings. He is an active member of different professional organizations. He was elected vice of Chair of IEEE Bangladesh section for three consecutive years of 2015, 16, 17. 